\title{
PENGARUH PENGGANTIAN SEBAGIAN RANSUM DENGAN TEPUNG DAUN DAN BATANG UBI JALAR (Ipomoea batatas) TERHADAP KECERNAAN PROTEIN DAN ENERGI PADA TERNAK BABI
}

\author{
Hendro F. V Salea, M. Najoan*, J. F. Umboh dan C. J. Pontoh \\ Fakultas Peternakan Universitas Sam Ratulangi Manado
}

\begin{abstract}
ABSTRAK
Ternak babi merupakan salah satu ternak potong penghasil daging yang dapat berkontribusi bagi pemenuhan kebutuhan protein hewani. Daun dan batang ubi jalar (Ipomoea batatas) merupakan limbah pertanian yang dapat dimanfaatkan sebagai pakan ternak babi. Penelitian ini bertujuan untuk mengetahui sejauh mana pengaruh penggunaan tepung daun dan batang ubi jalar menggantikan sebagian ransum terhadap kecernaan energi dan protein ternak babi. Penelitian ini menggunakan rancangan Bujur Sangkar Latin (Latin Square Design) 5 x 5 yang terdiri dari 5 ekor babi jantan kastrasi hasil persilangan Duroc X Spotted Polland China berumur sekitar 3,5 - 4,0 bulan, berat badan awal $50 \mathrm{~kg}( \pm 2.5 \mathrm{~kg})$ dan dialokasikan ke dalam 5 perlakuan sebagai berikut: R0 $=100 \%$ Ransum Dasar $+0 \%$ Daun dan Batang Ubi Jalar; R1 $=92,5 \%$ Ransum Dasar + 7,5 \% Daun dan Batang Ubi Jalar; R2 $=85 \%$ Ransum Dasar +15 $\%$ Daun dan Batang Ubi Jalar; R3 $=77,5 \%$ Ransum Dasar + 22,5\% Daun dan Batang Ubi Jalar; R4 $=70 \%$ Ransum Dasar +30 $\%$ Daun dan Batang Ubi Jalar. Parameter yang diukur yaitu: kecernaan energi dan protein ransum. Hasil penelitian menunjukan bahwa tidak ada perbedaan yang nyata $(\mathrm{P}>0,05)$ antar perlakuan terhadap kecernaan energi dan protein ransum. Hasil penelitian ini mengindikasikan bahwa penggunaan daun dan batang ubi jalar sampai dengan $30 \%$
\end{abstract}

*Korespondensi (corresponding Author) Email: najoanmarie@yahoo.com dalam ransum tidak mempengaruhi kecernaan energi dan protein ransum ternak babi fase finisher. Dapat disimpulkan bahwa daun dan batang ubi jalar dapat digunakan sampai dengan 30\% menggantikan ransum dasar pada ternak babi fase finisher tanpa adanya efek negatif terhadap kecernaan energi dan protein.

Kata Kunci : Tepung daun dan batang ubi jalar, kecernaan protein, kecernaan energi, ternak babi.

\section{ABSTRACT}

EFFECT OF PARTLY SUBSTITUTION OF BASAL DIET WITH SWEET POTATO VINES (Ipomoea batatas) MEAL ON ENERGY AND PROTEIN DIGESTIBILITY OF PIGS. Pork is one of the meat producer animals that can contribute to satisfy animal protein requirements. Sweet potato vines is considered as an agricultural waste product and can be used as feedstuff for pigs. The present study was conducted to determine the utilization of sweet potato vines substituting basal diet on energy and protein digestibility of finisher pigs. Five 'Duroc X Spotted Poland China' castrated male pigs, aged 3.5 to 4.0 months with an initial body weight $50 \mathrm{~kg}( \pm 2.5 \mathrm{~kg})$ were assigned to four treatments as follow: $\mathrm{R} 0=$ $100 \%$ basal diet $+0 \%$ sweet potato vines meal; $\mathrm{R} 1=92.5 \%$ basal diet $+7.5 \%$ sweet potato vines meal; R2 $=85 \%$ basal diet + $15 \%$ sweet potato vines meal; R3 $=77.5 \%$ basal diet $+22.5 \%$ sweet potato vines meal; and R4 $=70 \%$ basal diet $+30 \%$ sweet potato vines meal. Parameters measured 
were: energy and protein digestibility. Research reasults showed that there is no significant differences $(\mathrm{P}>0.05)$ among treatments on energy and protein digestibility of pigs in the present study. This indicated that utilization of sweet potato vines meal up to $30 \%$ replacing basal diet did not affect digestible energy and protein of finishing pigs. It can be concluded that substituting basal diet with sweet potato vines meal up to $30 \%$ has no negative effect on energy and protein digestibility of finishing pigs.

Keywords: Sweet potato vines, energy digestibility, protein digestibility, pigs

\section{PENDAHULUAN}

Ternak babi merupakan salah satu ternak lokal unggulan di daerah Sulawesi Utara, sudah dipelihara oleh masyarakat khususnya di daerah Minahasa dan sudah menjadi ternak budaya. Ternak babi memberikan kontribusi baik secara ekonomi, sosial, dan budaya bagi masyarakat di daerah ini. Peternakan babi merupakan salah satu usaha yang mempunyai peranan penting dalam memacu upaya peningkatan penyedian sumber protein hewani bagi masyarakat.

Ternak babi termasuk golongan omnivora monogastrik yaitu pemakan semua bahan makanan. Namun tidak semua bahan makanan yang masuk ke dalam saluran alat pencernaan dapat dimanfaatkan oleh ternak babi. Persentase yang dapat dicerna dan diserap dianggap sebagai koefisien kecernaan (\%). Daya cerna didasarkan atas suatu asumsi bahwa zat makanan yang tidak terdapat di dalam feses adalah habis untuk dicerna dan diabsorpsi. Kecernaan adalah selisih antara zat makanan yang dikonsumsi dengan yang dieksresikan dalam feses. Jadi kecernaan merupakan pencerminan dari kemampuan suatu bahan pakan yang dapat dimanfaatkan oleh ternak.

Protein dan energi merupakan dua faktor penting yang menentukan kualitas pakan dan harus memenuhi standar kebutuhan dalam ransum ternak. Ransum merupakan faktor terbesar (sekitar 60-70\%) dari biaya produksi. sehingga peningkatan ketersediaan bahan baku pakan perlu dilakukan guna meningkatkan produksi (Kaligis, 2017). Bahan baku pakan jagung, kedele, dan tepung ikan kebanyakan masih diimpor dan masih sering kompetitif dengan kebutuhan manusia (Rumerung, 2015).

Tanaman ubi jalar adalah salah satu jenis umbi-umbian yang banyak terdapat di daerah Sulawesi Utara dan harganya relatif murah. Badan Pusat Statistik (2012) menyatakan bahwa produktivitas ubi jalar di Indonesia setiap tahunnya mengalami peningkatan. Budidaya ubi jalar terutama untuk memproduksi umbi yang dapat dimanfaatkan untuk konsumsi manusia dan ternak, setelah dipanen akan menyisakan limbah berupa daun, tangkai, dan batang 
ubi jalar dalam jumlah yang besar. Komposisi kimia daun ubi jalar berdasarkan bahan kering yaitu bahan kering (BK) 88.46\%, protein kasar (PK) $25.51 \%$, Abu $14.22 \%$, serat kasar (SK) $24.29 \%$, lemak kasar (LK) $1.15 \%$, dan bahan ekstrak tanpa nitrogen (BETN) $34.70 \%$, kalsium $(\mathrm{Ca}) \quad 0.79 \%$ dan $(\mathrm{P})$ $0.38 \%$ (Nursiam, 2008).

Selama ini daun ubi jalar yang dikategorikan sebagai limbah pertanian masih belum banyak dimanfaatkan untuk pakan, khususnya ternak babi. Kandungan nutrien, khususnya protein kasar yang ada dalam daun ubi jalar memberikan peluang untuk dimanfaatkan sebagai pakan sumber protein untuk menggantikan bahan-bahan pakan sumber protein yang konvensional seperti tepung kedele, tepung ikan, dan lain sebagainya. Penelitian ini dirancang untuk mengetahui sejauh mana pengaruh penggunaan tepung daun dan batang ubi jalar menggantikan sebagian ransum ternak babi.

\section{MATERI DAN METODE PENELITIAN}

Penelitian ini dilaksanakan selama 50 hari dengan menggunakan 5 ekor babi jantan kastrasi hasil persilangan Duroc $\mathrm{X}$ Spotted Poland China berumur sekitar 3,5 4,0 bulan dengan berat badan awal $50 \mathrm{~kg}$ $( \pm 2,5 \mathrm{~kg})$. Kandang yang digunakan dalam penelitian ini yaitu kandang percobaan 5 unit dengan ukuran 150 x 125 x $100 \mathrm{~cm}$. Setiap kandang dilengkapi dengan tempat makan dan minum. Lantai kandang terbuat dari beton dan antar unit dibatasi sekat kayu.

Komponen Pakan (Ransum Percobaan) yang dipakai untuk menyusun ransum dasar (R0) adalah ransum dasar tanpa pemberian daun ubi jalar. Ke dalam ransum dasar (R0) ini, kemudian ditambahkan daun ubi jalar dengan beberapa tingkatan.

Komposisi Zat-zat Makanan dan Digestible Energi Bahan Pakan Penyusun Ransum dapat dilihat pada Table 1, sedangkan Komposisi Bahan Pakan dan Kandungan Zat-zat Makanan dan Digestible Energi Ransum Perlakuan dapat dilihat pada Tabel 2. Penelitian ini menggunakan rancangan bujur sangkar latin (Latin Square Design) 5 x 5 yang terdiri dari 5 ekor ternak babi. Sebagai perlakuan adalah tepung daun dan batang ubi jalar menggantikan sebagian ransum untuk ternak babi, penggantiannya diatur sebagai berikut:

$\mathrm{R} 0=100 \%$ Ransum dasar $+0 \%$ daun dan batang ubi jalar

$\mathrm{R} 1=92,5 \%$ Ransum dasar $+7,5 \%$ daun dan batang ubi jalar $\mathrm{R} 2=85 \%$ Ransum dasar $+15 \%$ daun dan batang ubi jalar 
Tabel 1. Komposisi Nutrien dan Digestible Energi Bahan Pakan Penyusun Ransum

\begin{tabular}{lccccccc}
\hline \multicolumn{1}{c}{ Bahan Pakan } & Protein & Lemak & $\begin{array}{c}\text { Serat } \\
\text { Kasar }\end{array}$ & Abu & Ca & P & DE \\
& & \multicolumn{7}{c}{$(\%)$} \\
\hline Jagung $^{1}$ & 9,42 & 5,17 & 2,15 & 15,13 & 0,22 & 0,60 & 3180 \\
Dedak $^{1}$ & 13,44 & 6,07 & 6,35 & 10,33 & 0,19 & 0,73 & 2873 \\
Bungkil Kelapa $^{1}$ & 24,74 & 9,36 & 15,02 & 6,95 & 0,11 & 0,47 & 3495 \\
Tepung Ikan $^{1}$ & 55,59 & 12,10 & 0,017 & 20,10 & 5,10 & 2,08 & 3699 \\
Tepung Kedele $^{2}$ & 40,38 & 9,91 & 6,56 & & 0,24 & 0,58 & 2708 \\
Minyak $^{1}$ & & 100,00 & & & & & 9395 \\
Mineral Mix $^{1}$ & & & & & 5,38 & 1,44 & \\
Daun Ubi Jalar $^{3}$ & 16,72 & 3,16 & 25,81 & 13,19 & 1,09 & 0,62 & 3581 \\
\hline
\end{tabular}

Ket: ${ }^{1}$ Laboratorium Ruminansia \& Kimia Makanan Fakultas Peternakan Unpad,

Bandung (Dengah et al., 2016)

${ }^{2}$ Kowel (2007).

${ }^{3}$ Laboratorium Ilmu dan Teknologi Pakan Fakultas Peternakan, IPB (2017)

Tabel 2. Komposisi Bahan Pakan dan Kandungan Zat-zat Makanan dan Digestible Energi Ransum Perlakuan

\begin{tabular}{lccccc}
\hline \multicolumn{1}{c}{ Bahan Pakan } & R0 & R1 & R2 & R3 & R4 \\
\hline Jagung & 60 & 60 & 60 & 60 & 60 \\
Dedak & 19 & 19 & 19 & 19 & 19 \\
Bungkil Kelapa & 3 & 3 & 3 & 3 & 3 \\
Tepung Ikan & 10 & 10 & 10 & 10 & 10 \\
Tepung Kedele & 7 & 7 & 7 & 7 & 7 \\
Mineral Mix & 1 & 1 & 1 & 1 & 1 \\
\hline \multicolumn{1}{c}{ Total } & 100 & 100 & 100 & 100 & 100 \\
\hline Ransum Dasar & 100 & 92,5 & 85 & 77,5 & 70 \\
Daun Ubi Jalar & 0 & 7,5 & 15 & 22,5 & 30 \\
\hline Kandungan Nutrien & & & & & \\
\hline Protein & 17,33 & 17,94 & 17,24 & 17,19 & 17,14 \\
Lemak & 6,43 & 6,19 & 5,94 & 5,70 & 5,45 \\
Serat Kasar & 3,40 & 5,08 & 6,76 & 8,44 & 10,12 \\
Ca & 0,75 & 0,77 & 0,80 & 0,82 & 0,85 \\
P DE (Kkal/kg) & 0,77 & 0,76 & 0,75 & 0,74 & 0,72 \\
DE & 3118 & 3152 & 3187 & 3222 & 3257 \\
\hline
\end{tabular}

$\mathrm{R} 3=77,5 \%$ Ransum dasar $+22,5 \%$ daun dan batang ubi jalar

$\mathrm{R} 4=70 \%$ Ransum dasar $+30 \%$ daun dan batang ubi jalar.

\section{Variabel yang diukur}

Untuk melihat pengaruh penggantian sebagian ransum dengan tepung daun dan batang ubi jalar, variable 
penelitian yaitu kecernaan energi dan protein sesuai petunjuk Benerjee (1978).

1. Kecernaan Energi; dihitung berdasarkan rumus yang dikemukakan sebagai berikut:

$\mathrm{KCE}=\frac{(\text { Kons } \mathrm{x} \mathrm{EB})-\left(\sum F e s \times E B F e s\right)}{(\text { Kons } \mathrm{xEB})} \times 100$

Ket.

$\mathrm{KCE}=$ koefisien cerna semu energi ransum $(\%)$

Kons $=$ jumlah ransum yang dikonsumsi $(\mathrm{g} / \mathrm{h} / \mathrm{e})$

$\mathrm{EB}=$ energi bruto ransum $(\mathrm{kkal} / \mathrm{g})$

$\sum \mathrm{Fes}=$ jumlah feses yang didefikasi $(\mathrm{g} / \mathrm{h} / \mathrm{e})$

EB Fes $=$ energi bruto feses $(\mathrm{kkal} / \mathrm{g})$

2. Kecernaan Protein; dihitung sama halnya dengan menghitung $\mathrm{KCE}$ :

$\mathrm{KCP}=\frac{(\text { Kons } \mathrm{x} \% \text { Prot })-(\text { Fes } x \% \text { Prot Fes })}{\text { (Kons } \mathrm{x} \% \text { Prot })} \mathrm{X} 100$

Ket.

$\mathrm{KCP}=$ Koefisien cerna protein kasar ransum $(\%)$

Kons = Jumlah ransum yang dikonsumsi

$\sum \mathrm{Fes}=$ jumlah feses yang didefikasi $(\mathrm{g} / \mathrm{h} / \mathrm{e})$

\section{Tatalaksana Penelitian}

a. Masa Pendahuluan : Pada awal masa pendahuluan, semua ternak percobaan diberi obat cacing untuk membebaskan ternak babi dari pengaruh cacing atau parasit usus. Kemudian dilanjutkan dengan pemberian obat diare. Makanan diberikan setiap hari dimulai dari jam 07:00 pagi sesudah kandang dan ternak dibersihkan kemudian sisa makanan ditimbang setiap hari selama pengumpulan data. Ransum sisa ditimbang pada pukul 08:00 besok harinya. Makanan dan air minum diberikan secara ad libitum selama 7 hari pertama, pada hari ke 8 hitung rata-rata konsumsi perekor, kemudian hari ke $8-10$ berikan ransum $80 \%$ dari rata-rata konsumsi selama 7 hari pertama, dengan tujuan makanan yang diberikan tidak ada yang tersisa.

b. Masa Pengumpulan Data. Selama masa pengumpulan data (fecal collecting) yaitu pada hari ke $8-10$, ransum diberikan sebanyak $80 \%$ dari rata-rata konsumsi selama 7 hari pertama. Feses di ambil pada hari ke $9-11$. Sampel feses segar yang tidak terkontaminasi diambil sebanyak $20 \%$ dari jumlah feses setiap defikasi. Feses yang sudah terkumpul kemudian dikeringkan dengan sinar matahari setelah itu dikeringkan menggunakan oven kemudian digiling lalu diambil sampel untuk dianalisis di laboratorium.

c. Penggelolahan Data. Data hasil penelitian ditabulasi dan dianalisis keragamannya (Anova) sesuai dengan petunjuk rancangan percobaan yang digunakan. 


\section{HASIL DAN PEMBAHASAN}

Hasil penelitian tentang pengaruh penggunaan tepung daun dan batang ubi jalar menggantikan sebagian ransum terhadap kecernaan energi dan protein ternak babi, dapat dilihat pada Tabel 3 .

\section{Pengaruh perlakuan terhadap kecernaan energi ternak babi}

Kecernaan energi dalam penelitian ini berkisar antara 80,48-82,09\%. Angka kecernaan tertinggi pada perlakuan R3 (substitusi 22,5\% daun dan batang ubi jalar dalam ransum) yaitu sebesar 82,09\%. Kecernaan energi paling rendah pada perlakuan R1 (substitusi 7,5\% daun dan batang ubi jalar dalam ransum) yaitu sebesar 80,48\%. Kisaran angka kecernaan energi dalam penelitian ini masih berada dalam kisaran sebagaimana yang dikutip dari beberapa sumber dan penelitian, di mana 70 - 90\% merupakan kisaran angka normal untuk kecernaan energi (Utama et al., 2016). NRC (1988) juga menyatakan bahwa kecernaan energi pada ternak babi fase grower-finisher berkisar antara 70-85\% tergantung bahan pakan sumber energi yang digunakan.

Hasil analisis keragaman nilai kecernaan energi ransum dalam penelitian ini menunjukkan bahwa perlakuan memberikan pengaruh yang tidak nyata
$(\mathrm{P}>0,05)$ terhadap kecernaan energi ransum.

Hal ini mengindikasikan bahwa penggunaan daun dan batang ubi jalar hingga $30 \%$ dalam ransum belum memberikan pengaruh terhadap kecernaan energi pada ternak babi. Tidak adanya pengaruh perlakuan terhadap kecernaan disebabkan oleh kandungan energi ransum yang relatif sama, walaupun setiap perlakuan dengan level penggunaan daun dan batang ubi jalar yang berbeda untuk tiap ransum $(0 \%, 7,5 \%, 15 \%, 22,5 \% 30 \%)$ tetapi memiliki nilai daya cerna pakan yang relatif sama. Hal ini berarti kemampuan ternak dalam mencerna makanan, kecukupan zat-zat nutrisi ransum relatif sama untuk memenuhi kebutuhan hidup pokok dan pertumbuhan.

Kecernaan energi dipengaruhi oleh jumlah konsumsi makanan. Semakin tinggi konsumsi energi dalam ransum akan menekan konsumsi zat-zat makanan lainnya termasuk konsumsi protein, sebaliknya semakin rendah konsumsi energi semakin tinggi konsumsi zat-zat makanan lainnya termasuk konsumsi protein (Church, 1984; Patience and Thacker, 1995). Tidak adanya perbedaan yang nyata terhadap kecernaan energi dalam penelitian ini diduga karena jumlah konsumsi ransum yang hampir sama dan komposisi zat-zat makanan dalam ransum perlakuan juga hampir sama. 
Tabel 3. Rataan Kecernaan Energi Dan Protein Ransum Ternak Babi

\begin{tabular}{lccccc}
\hline Kecernaan & \multicolumn{5}{c}{ Perlakuan } \\
\cline { 2 - 6 } & R0 & R1 & R2 & R3 & R4 \\
\hline Energi (\%) & 81,02 & 80,48 & 81,46 & 82,09 & 81,23 \\
Protein (\%) & 82,23 & 82,21 & 81,34 & 82,05 & 82,35 \\
\hline
\end{tabular}

Ket: Antar perlakuan tidak berbeda nyata $(\mathrm{P}<0.05)$

\section{Pengaruh perlakuan terhadap kecernaan protein ternak babi}

Kecernaan protein dalam penelitian ini berkisar antara 81,34-82,35\%. Kecernaan protein tertinggi pada perlakuan R4 (substitusi 30\% daun dan batang ubi jalar dalam ransum) yaitu $82,35 \%$ dan kecernaan protein paling rendah pada perlakuan R2 (substitusi $15 \%$ daun dan batang ubi jalar dalam ransum) yaitu $81,34 \%$. Kisaran angka kecernaan protein dalam penelitian ini juga masih dalam kisaran atau rekomendasi dari beberapa sumber dan penelitian di antaranya Sihombing (2006); Tulung et al. (2015); Pelealu (2009) yang melaporkan angka kecernaan protein babi fase finisher berkisar $75-90 \%$.

Hasil analisis keragaman nilai kecernaan protein ransum dalam penelitian ini memberikan pengaruh yang tidak nyata $(\mathrm{P}>0,05)$ antar perlakuan. Hal ini mengindikasikan bahwa penggunaan daun dan batang ubi jalar hingga 30\% dalam ransum belum memberikan pengaruh terhadap kecernaan protein pada ternak babi. Tidak adanya pengaruh perlakuan terhadap kecernaan disebabkan oleh kandungan nutrisi ransum yaitu protein yang relatif sama, Walaupun setiap perlakuan dengan level penggunaan daun dan batang ubi jalar yang berbeda untuk tiap ransum $(0 \%, 7,5 \%, 15 \%, 22,5 \%, 30 \%)$ tetapi memiliki nilai daya cerna yang relatif sama. Hal ini berarti kemampuan ternak dalam mencerna makanan, kecukupan zatzat nutrisi ransum relatif sama untuk memenuhi kebutuhan.

Kecernaan protein dipengaruhi oleh jumlah konsumsi makanan. Semakin tinggi konsumsi energi dalam ransum akan menekan konsumsi zat-zat makanan lainnya termasuk konsumsi protein, sebaliknya semakin rendah konsumsi energi semakin tinggi konsumsi zat-zat makanan lainnya termasuk konsumsi protein (Church, 1984; Patience dan Thacker, 1995). Tidak adanya perbedaan terhadap kecernaan energi dan protein dalam penelitian ini diduga karena jumlah konsumsi ransum yang hampir sama dan komposisi zat-zat makanan dalam ransum perlakuan juga hampir sama.

Sihombing (2006) menyatakan jumlah konsumsi ransum sangat dipengaruhi oleh tingkat energi dan protein 
ransum. Kandungan protein dan energi yang sama dalam ransum akan menghasilkan jumlah konsumsi ransum yang tidak berbeda nyata, ternak babi sangat memerlukan energi, protein, mineral, vitamin dan air. Kekurangan atau ketidakseimbangan zat-zat makanan dapat memperlambat pertumbuhan dan berdampak pada performans. Mateos et al. (2006) menyatakan tingkat serat kasar untuk ternak babi yang sedang tumbuh minimum $6 \%$, sedangkan tingkat serat kasar dalam ransum (Tabel.4) meningkat seiring dengan meningkatnya level pemberian daun dan batang ubi jalar sampai dengan 30\% dengan nilai serat kasar $10,12 \%$, namun belum mempengaruhi kecernaan. Lebih lanjut bahwa serat kasar terdiri dari komponen yang larut (soluble dietary fiber, $S D F$ ) dan komponen yang tidak larut (insoluble dietary fiber, IDF). Diduga karena sifat serat kasar dari daun ubi jalar yaitu bersifat komponen yang larut (soluble dietary fiber, $S D F)$.

Tidak adanya perbedaan yang nyata $(\mathrm{P}>0,05)$ antar perlakuan dalam penelitian ini mengindikasikan bahwa daun dan batang ubi jalar dapat menggantikan $30 \%$ ransum ternak babi.

Hasil penelitian ini lebih menjelaskan bahwa ekspektasi dalam penelitian ini tercapai karena dapat memanfaatkan daun dan batang ubi jalar yang dianggap sebagai limbah pertanian dapat menjadi bahan pakan alternatif dalam ransum ternak babi. Jadi hasil penelitian ini merupakan suatu terobosan dalam menemukan bahan-bahan pakan non konvensional untuk menggantikan bahanbahan pakan konvensional dalam ransum ternak babi.

\section{KESIMPULAN}

Daun dan batang ubi jalar dapat digunakan sampai dengan $30 \%$ menggantikan ransum dasar pada ternak babi fase finisher tanpa adanya efek negatif terhadap kecernaan energi dan protein.

\section{DAFTAR PUSTAKA}

Badan Pusat Statistik. 2012. Perkembangan produksi ubi jalar Indonesia.

Banerjee, G.C. 1978. Animal Nutrition. Oxford \& IBM Pub. Co Calcutta.

Church, D.C. 1984. Factors Affecting Feed Consumption. In : D.C. Church Livestock Feed and Feeding. Durham and Downey. Inc. London. Pp 136139

Dengah, S., J. F. Umboh, C. A. Rahasia, Y. H. S. Kowel. 2016. Pengaruh penggantian tepung ikan dengan tepung manggot (Hermetia Illucens) dalam ransum terhadap performans broiler. Jurnal Zootek 36(1): 51 - 60 .

Kaligis, F.S. 2017. Pengaruh substitusi dedak halus dengan tepung kulit buah kopi dalam ransum terhadap kecernaan energy dan protein pada 
ternak babi fase grower. Jurnal Zootek 37(2) : 199 - 206.

Kowel, Y.H.S. 2007. Pengaruh Penggunaan Limbah Minyak Pengalengan ikan dalam Ransum Terhadap Efisiensi Biologis dan Kualitas Karkas Broiler. Tesis. Universitas Sam Ratulangi. Program Pascasarjana. Manado.

Mateos, G.G., F. Martin, M.A. Latorre, B. Vicente, R. Lazaro. 2006. Inclusion of oat hulls in diets for young pigs based on cooked maize or cooked rice. J Anim Sci. 82:57-63.

N.R.C. 1988. Nutrient Requirements of Domestic Animals. Nutrient Requirements of Swine. $9^{\text {th }}$ Rev. Ed. National Academy of sciences. pp. 255.

Nursiam. I. 2008. Pemanfaatan daun ubi jalar (ipomoea batatas) sebagai pakan ternak. Fak. Peternakan. IPB.

Patience, J dan P.A. Thacker. 1995. Swine Nutrition Guide. Publ. by Prairie Swine Center, University of Saskatchewan, Saskatoon, Canada.

Pelealu, I. 2009. Efek Pemberian Konsentrat Pabrikan dan Buatan
Sendiri Terhadap Kecernaan Protein Dan Energi Ternak Babi Fase Grower. Skripsi. Fakultas Peternakan Universitas Sam Ratulangi Manado.

Rumerung, S.N. 2015. Efek penggunaan konsentrat pabrikan dan buatan sendiri dalam ransum babi starter terhadap efisiensi penggunaan ransum. Jurnal Zootek 35(2): 295301.

Sihombing, D.T.H. 2006. Ilmu Ternak Babi. Gadjah Mada University Press Yogyakarta.

Tulung, C., J.F. Umboh, F.N. Sompie dan C.J. Pontoh. 2015. Pengaruh penggunaan Virgin Coconut Oil (VCO) dalam ransum terhadap kecernaan energi dan protein ternak babi fase grower. Jurnal Zootek. 35(2): 319-327.

Utama, I.A.P.P., I.K. Sumadi dan I.P.A. Astawa. 2016. Pengaruh level energi dan protein ransum terhadap kecernaan ransum pada babi bali jantan lepas sapih. Journal of Tropical Animal Science 4(3): 529544. 